\title{
Hubungan Karakteristik Individu (Jenis Kelamin dan Usia) Dengan Perkembangan Psikososial Mahasiswa Keperawatan di Surabaya
}

\author{
Diyan Mutyah \\ Stikes Hang Tuah Surabaya. diyanmutyah@gmail.com \\ Sukma Ayu Ck \\ Stikes Hang Tuah Surabaya. sukmakirana.89@gmail.com \\ Nisha Damayanti \\ Stikes Hang Tuah Surabaya. nishadr.shtsby@gmail.com
}

\begin{abstract}
Abstrak
Usia dewasa merupakan tahapan yang diawali dengan masa transisi dari masa remaja hingga masa dewasa yang melibatkan pengalaman dan eksplorasi yang disebut dengan emerging adulthood. Tahap perkembangan psikososial manusia dimana individu mulai menerima dan memikul tanggung jawab yang lebih berat. Tahap usia dewasa ini hubungan intim mulai didalami dan mengalami perkembangan, hal ini sejalan dengan masa reproduktif yang mulai sempurna. Keintiman yaitu individu mampu membina hubungan intim/dekat dan cinta dengan orang lain.Tujuan dari penelitian ini yaitu mendapatkan gambaran perkembangan psikososial mahasiswa keperawatan di wilayah Surabaya. Metode Penelitian yang digunakan adalah deskriptif analitik dengan menggunakan teknik sampling kuota sampling dengan jumlah sampel 150 mahasiswa keperawatan dari 2 intitusi keperawatan wilayah Surabaya. Hasil dalam penelitian ini sebagian besar perkembangan psikososisal kurang optimal dengan 52 responden $(34,7 \%)$, disebabkan karena faktor umur yang sebagian besar berusia 18 tahun. Penelitian ini menunjukkan ada hubungan yang signifikan antara perkembangan psikososial mahasiswa dengan jenis kelamin. Perlu adanya kegiatan yang dapat menunjang perkembangan psikososial pada mahasiswa, terutama dalam menunjang perkembangan intimasi menjadi optimal. Kegiatan yang dapat dilakukan seperti sharing antara mahasiswa dengan dosen dan perlu peran aktif mahasiswa dalam melatih diri untuk meningkatkan perkembangan intimasi.
\end{abstract}

Kata Kunci: Perkembangan Psikosial, Usia, Jenis Kelamin

\begin{abstract}
Adult age is a stage that begins with the transition from adulthood to adulthood which involves experience and discussion called the emergence of adulthood. Young adulthood is a stage of human psychosocial development where individuals begin to accept and assume heavier responsibilities. At this stage of age, intimate relationships begin to be explored and experienced development, this is in line with the reproductive period that starts perfect. Intimacy is how individuals are able to foster intimate / close relationships and love with others. The purpose of this study is to get a description of the psychosocial development of nursing students in the Surabaya area using an intimacy questionnaire. The research method used was descriptive analytic using quota sampling and a sample of 150 nursing students from 2 nursing institutions in Surabaya. The results of this study which examined the psychosocotic development in young adults showed that the majority of psychososisal development was less than optimal with 52 respondents (34.7\%), because the age factor was mostly 18 years. 4 . There is a significant relationship between the psychosocial development of students and the gender of Chi-square students $\mathrm{P}=$ 0.007. So the need for activities that can support psychosocial development in students, especially in supporting the development of intimacy so that the development of intimacy in students can be optimal. Activities that can be carried out such as sharing activities between students and lecturers so that lecturers can help students in fulfilling their
\end{abstract}


development tasks, and students need to play an active role in training themselves to improve the development of intimacy in themselves.

Keywords: Psychosocial Development, Age, Gender

\section{PENDAHULUAN}

Usia produktif adalah usia dimana seseorang penduduk memiliki usia 15-64 tahun. Indonesia memiliki generasi muda sebanyak $60 \%$ dari total penduduk Indonesia yang mencapai 250 juta jiwa, hal ini berarti bahwa populasi produktif di Indonesia dapat mencapai 195 juta jiwa pada 2040 nanti. Peningkatan usia produktif tersebut dapat meningkatkan perekonomian nasional (Indonesia 2017). Ahli lain Hurlock (1980) membagi dewasa menjadi dewasa muda (18-40 tahun), dewasa madya (4060 tahun), dan masa dewasa lanjut (60 tahun sampai dengan kematian) (Varcarolis, 2010 ; Fortinash and Worret, 2012).

Usia dewasa merupakan tahapan yang diawali masa transisi dari remaja hingga dewasa yang melibatkan pengalaman dan eksplorasi yang disebut dengan emerging adulthood (Papalia, Olds, and Feldman 2008). Menurut teori Erikson, usia dewasa muda adalah tahap perkembangan psikososial manusia dimana individu mulai menerima dan memikul tanggung jawab yang lebih berat. Tahap usia dewasa ini hubungan intim mulai didalami dan mengalami perkembangan, hal ini sejalan dengan masa reproduktif yang mulai sempurna. Selain itu terdapat beberapa perubahan yang terjadi dalam penampilan, minat, sikap dan perilaku (Pieter, Janiwarti, and Saragih 2011). Periode penyesuaian diri terhadap perubahan peran juga harus dilalui pada tahap ini yaitu berperan sebagai mahasiswa, suami atau istri, orang tua. Hal ini juga dialami oleh mahasiswa keperawatan yang berada dalam tahap dewasa muda. Apabila seseorang tidak bisa melewati masa perkembangan tersebut maka terjadi penyimpangan sosial pada tahap keintiman dan tidak terjadi perkembangan.

Berdasarkan hasil studi pendahuluan pada mahasiswa STIKES Hang Tuah Surabaya Program Studi S1 Keperawatan, didapatkan data bahwa 7 dari 15 mahasiswa tidak tinggal bersama dengan keluarganya. Hasil wawancara yang didapatkan adalah mahasiswa tersebut merasa tidak nyaman karena harus mempersiapkan kebutuhan dirinya secara mandiri. Selain itu mahasiswa juga mengatakan bahwa dirinya bebas dari orang tua dan bisa melakukan apa saja bahkan bebas dari pertanyaan seputar akademik mereka selama perkuliahan. Namun 8 orang mahasiswa lainnya lebih 
Diyan Mutyah, Sukma Ayu Ck., Nisha Damayanti Hubungan Karakteristik Individu (Jenis Kelamin dan Usia) Dengan Perkembangan Psikososial Mahasiswa Keperawatan di Surabaya

senang berada di kos dan hanya keluar untuk beli makan atau mengerjakan tugas. Lebih suka menyendiri dikamar daripada menjalin hubungan dengan teman sebayanya. 4 dari 8 mahasiswa tersebut mengaku bahwa belum pernah menjalin hubungan dengan lawan jenis karena ingin fokus berkuliah dan tidak ingin terganggu dengan masalah lain di luar studi yang mereka jalani.

Hubungan intim yang terbentuk merupakan salah satu tugas perkembangan psikososial yang harus dipenuhi pada tahap perkembangan usia dewasa muda (Erikson 1969, dalam Papalia et al., 2008). Mampu berkomitmen dalam pekerjaan, mandiri dalam kehidupan pribadi, bertanggung jawab secara ekonomi, sosial dan emosional, memiliki konsep diri yang realistis, menyukai dirinya dan mengetahui tujuan hidup, berinteraksi dengan baik dengan keluarga, mengatasi stress akibat perubahan diri, serta menjadikan kehidupan sosial bermakna dan mempunyai nilai yang dijadikan pedoman hidupnya merupakan perilaku yang seharusnya dimiliki individu dewasa muda (Shaft, 2012 dalam Azizah, 2015).

Apabila individu dewasa muda mampu membentuk persahabatan dan hubungan dekat yang sehat dengan individu yang lain, maka intimasi dapat terwujud (Santrock 2003). Harapan mahasiswa untuk lulus tepat waktu, mendapatkan pekerjaan sesuai dengan yang diharapkan dan menghasilkan uang agar bisa membahagiakan orang tua dapat menjadi tekanan bagi mahasiswa itu sendiri. Oleh sebab itu peneliti ingin mengetahui gambaran perkembangan psikososial mahasiswa keperawatan di wilayah Surabaya.

\section{METODE}

Penelitian ini menggunakan desain penelitian deskriptif analitik karena penelitian bertujuan untuk mendeskripsikan dan melihat hubungan usia dan jenis kelamin terhadap perkembangan psikososial mahasiswa keperawatan di Surabaya. Teknik sampling yang digunakan dalam penelitian ini adalah kuota sampling dimana pengambilan sampel mahasiswa keperawatan sesuai dengan kriteria yang ditentukan oleh peneliti. Sampel dari penelitian ini adalah 150 mahasiswa keperawatan dari 2 intitusi keperawatan wilayah Surabaya.

\section{HASIL PENELITIAN}

\section{Data Umum}

Tabel 1 Frekuensi data umum Psikososial pada Dewasa Muda $(n=150)$. 
61 | Jurnal Ilmiah Kesehatan (Journal of Health Sciences), Vol. 13, No. 1, Februari 2020, Hal. 58-65

\begin{tabular}{ccccc}
\hline No. & \multicolumn{2}{c}{$\begin{array}{c}\text { Karakteristik } \\
\text { Responden }\end{array}$} & Jumlah & $\%$ \\
\hline 1. & Umur & 18 Tahun & 52 & 34,7 \\
& & 19 Tahun & 38 & 25,3 \\
& & 20 Tahun & 46 & 30,7 \\
& & 21 Tahun & 13 & 8,7 \\
& 23 Tahun & 1 & 0,7 \\
& Total & & $\mathbf{1 5 0}$ & $\mathbf{1 0 0}$ \\
\hline 2. & Jenis & Laki-laki & 20 & 13,3 \\
& Kelamin & & \\
& & Perempuan & 130 & 86,7 \\
& Total & & $\mathbf{1 5 0}$ & $\mathbf{1 0 0}$ \\
\hline
\end{tabular}

Tabel 1 diperoleh hasil dari 150 responden dengan karakteristik responden berdasarkan usia dari 150 responden dewasa awal (18 - 23) responden yang paling banyak adalah responden dengan usia 20 tahun sebanyak 46 responden $(30,7 \%)$ dan usia 19 tahun sebanyak 38 responden $(25,3 \%)$. Sedangkan dari 150 responden dengan karakteristik responden berdasarkan jenis kelamin mahasiswa bahwa mayoritas responden dalam penelitian adalah perempuan yaitu sebanyak 130 orang $(86,7 \%)$.

\section{Data Khusus}

Tabel 2 Frekuensi data khusus Psikososial pada Dewasa Muda $(\mathrm{n}=150)$

\begin{tabular}{|c|c|c|}
\hline Psikososial & Frekuensi & Presentase $(\%)$ \\
\hline Sangat Optimal & 1 & $0,7 \%$ \\
\hline Optimal & 24 & $16, \%$ \\
\hline Cukup Optimal & 39 & $26, \%$ \\
\hline Kurang Optimal & 52 & $34, \%$ \\
\hline $\begin{array}{l}\text { Sangat Kurang } \\
\text { Optimal }\end{array}$ & 34 & $22, \%$ \\
\hline Total & 150 & $100 \%$ \\
\hline Mean \pm SD & \multicolumn{2}{|c|}{$159,57 \pm 11,749$} \\
\hline Min - Max & \multicolumn{2}{|l|}{$124-188$} \\
\hline
\end{tabular}

penelitian psikososial pada dewasa muda dengan psikososial dari 150 responden didapatkan bahwa paling banyak mahasiswa dengan psikososial kurang optimal sebanyak 52 mahasiswa (34\%), dan psikososial optimal sebanyak 1 orang $(0,7 \%), \quad($ Mean \pm SD159,57 $\pm 11,749)$.

\section{Data Khusus}

Tabel 3 Hubungan perkembangan psikososial terhadap usia mahasiswa Keperawatan di Surabaya $(\mathrm{n}=150)$

\begin{tabular}{|c|c|c|c|c|c|c|c|c|c|c|c|c|}
\hline \multirow{3}{*}{ Usia } & \multicolumn{10}{|c|}{ Perkembangan Psikososial } & & \\
\hline & \multicolumn{2}{|c|}{$\begin{array}{c}\text { Sangat } \\
\text { optimal }\end{array}$} & \multicolumn{2}{|c|}{ optimal } & \multicolumn{2}{|c|}{$\begin{array}{c}\text { Cukup } \\
\text { Optimal }\end{array}$} & \multicolumn{2}{|c|}{$\begin{array}{l}\text { Kurang } \\
\text { Optimal }\end{array}$} & \multicolumn{2}{|c|}{$\begin{array}{l}\text { Sangat } \\
\text { kurang } \\
\text { optimal }\end{array}$} & \multicolumn{2}{|c|}{ TOTAL } \\
\hline & $\mathrm{F}$ & $\%$ & $\mathrm{~F}$ & $\%$ & $\mathrm{~F}$ & $\%$ & $\mathrm{~F}$ & $\%$ & $\mathrm{~F}$ & $\%$ & $\mathrm{~N}$ & $\%$ \\
\hline 18 Tahun & 1 & $1.9 \%$ & 8 & $33.3 \%$ & 3 & $7.7 \%$ & 21 & $40.4 \%$ & 19 & $55.9 \%$ & 52 & $34.7 \%$ \\
\hline 19 Tahun & 0 & $0.0 \%$ & 6 & $25.0 \%$ & 13 & $33.3 \%$ & 14 & $26.9 \%$ & 5 & $14.7 \%$ & 38 & $25.3 \%$ \\
\hline 20 Tahun & 0 & $0.0 \%$ & 10 & $41.7 \%$ & 15 & $38.45 \%$ & 11 & $21.2 \%$ & 10 & $29.4 \%$ & 46 & $30.7 \%$ \\
\hline 21 Tahun & 0 & $0.0 \%$ & 0 & $0.0 \%$ & 7 & $17.9 \%$ & 6 & $11.5 \%$ & 0 & $0.0 \%$ & 13 & $8.7 \%$ \\
\hline 23 Tahun & 0 & $0.0 \%$ & 0 & $0.0 \%$ & 1 & $2.6 \%$ & 0 & $0.0 \%$ & 0 & $0.0 \%$ & 0 & $0.7 \%$ \\
\hline Total & 1 & $100 \%$ & 24 & $100 \%$ & 39 & $100 \% \%$ & 52 & $100 \%$ & 34 & $100 \%$ & & 100 \\
\hline
\end{tabular}

Berdasarkan tabel 3 Menunjukkan perkembangan psikososial dewasa awal berhubungan dengan usia mahasiswa keperawatan di Surabaya didapatkan responden perkembangan psikososial kurang optimal dengan usia 18 tahun 
sebanyak 21 mahasiswa $(40.4 \%)$ dan perkembangan psikososial kurang optimal dengan usia 19 sebanyak 14 mahasiswa (26.9\%), perkembangan psikososial kurang optimal dengan usia 20 tahun sebanyak 11 mahasiswa (21.2\%) dan perkembangan psikososial kurang optimal dengan usia 21 sebanyak 6 mahasiswa $(11.5 \%)$, dan perkembangan psikososial kurang optimal dengan usia 23 sebanyak 0 mahasiswa $(0.0 \%)$.

\section{Data Khusus}

Tabel 4 Hubungan perkembangan psikososial dewasa muda terhadap jenis kelamin mahasiswa keperawatan di Surabaya $(n=150)$

\begin{tabular}{|c|c|c|c|c|c|c|c|c|c|c|c|c|}
\hline \multicolumn{13}{|c|}{ Perkembangan Psikososial } \\
\hline \multirow[t]{2}{*}{$\begin{array}{l}\text { Jenis } \\
\text { kelamin } \\
\end{array}$} & \multicolumn{2}{|c|}{$\begin{array}{l}\text { Sangat } \\
\text { optimal }\end{array}$} & \multicolumn{2}{|c|}{ optimal } & \multicolumn{2}{|c|}{ Cukup Optimal } & \multicolumn{2}{|c|}{$\begin{array}{l}\text { Kurang } \\
\text { Optimal }\end{array}$} & \multicolumn{2}{|c|}{$\begin{array}{l}\text { Sangat kurang } \\
\text { optimal }\end{array}$} & \multicolumn{2}{|c|}{ TOTAL } \\
\hline & $\mathrm{F}$ & $\%$ & $\mathrm{~F}$ & $\%$ & $\mathrm{~F}$ & $\%$ & $\mathrm{~F}$ & $\%$ & $\mathrm{~F}$ & $\%$ & $\mathrm{~N}$ & $\%$ \\
\hline Perempuan & 1 & $100 \%$ & 24 & $100 \%$ & 29 & $74.4 \%$ & 46 & $88.5 \%$ & 30 & $88.2 \%$ & 130 & $86.7 \%$ \\
\hline Laki-laki & 0 & 0.0 & 0 & $0.0 \%$ & 10 & $25.6 \% \%$ & 6 & $11.5 \%$ & 4 & $11.8 \%$ & 20 & $13.3 \%$ \\
\hline Total & 1 & $100 \%$ & 24 & $100 \%$ & 39 & $100 \%$ & 52 & $100 \%$ & 34 & $100 \%$ & 150 & $100 \%$ \\
\hline & & & & & Chi & uare ; & & & & & & \\
\hline
\end{tabular}

Berdasarkan tabel 4 Menunjukkan perkembangan psikososial dewasa awal berhubungan dengan jenis kelamin mahasiswa keperawatan di Surabaya didapatkan responden perkembangan psikososial kurang optimal dengan jenis kelamin perempuan sebanyak 46 mahasiswa $(88.5 \%)$ dan perkembangan psikososial kurang optimal dengan jenis kelamin laki-laki sebanyak 6 mahasiswa (11.5\%) dan perkembangan psikososial optimal dengan jenis kelamin perempuan sebanyak 24 mahasiswa (100\%)

Menurut hasil uji statistik Chi-square didapatkan hasil $\rho=0.007$ dimana $\rho \leq$ 0,05 terdapat hubungan antara perkembangan psikososial dewasa muda terhadap jenis kelamin pada mahasiswa keperawatan di Kota Surabaya.

\section{PEMBAHASAN}

Dewasa muda merupakan rentang usia di mana individu memiliki lebih banyak sahabat dan lebih banyak menghabiskan waktu bersama sahabat mereka. Dewasa muda yang memiliki jumlah sahabat terbanyak yaitu pada individu yang dalam jenjang perkuliahan (Blieszer dan Adams, dalam Latifah, 2005).

Erikson menjelaskan perkembangan psikosial dewasa muda berada pada tahap keintiman versus perpisahan. Individu akan mulai mencoba untuk menjalin hubungan dengan individu lain dan membentuk keakraban dan persahabatan 
(Hidayat 2009). Persahabatan dan hubungan sehat yang telah terjalin antara individu satu dengan individu yang lain dapat menjadi sebuah wujud intimasi pada dewasa muda. Namun, apabila individu tidak mampu mengembangkan diri sesuai dengan tahap perkembangan psikososial, maka individu dapat memisahkan diri dengan individu lain. Individu akan lebih memilih untuk menarik diri dari aktivitas sosial dan lebih memiliki sedikit hubungan dengan individu lain (Santrock 2003). Kemampuan individu dalam bersosialisasi, berkomunikasi, dan menjalin hubungan dengan individu lain dapat dipengaruhi oleh emosi (Potter and Perry 2005) sehingga individu perlu memiliki kecerdasan emosional. Kecerdasan emosional dapat disebut sebagai kecerdasan interpersonal, di mana individu mengetahui cara dalam memahami diri sendiri dan individu lain, menjalin hubungan dengan individu lain, serta mampu beradaptasi dengan lingkungan (Wiska 2014).

Perkembangan psikososial dapat dipengaruhi oleh usia dan jenis kelamin. Individu yang berusia lebih tua lebih mampu memahami diri sendiri dan individu lain serta lebih baik dalam menjalin hubungan dengan individu lain (Wiska 2014). Individu yang memiliki usia di atas 21 tahun memiliki kemampuan yang lebih baik dalam menjalin hubungan dengan individu lain (Ishak et al. 2011).

Selain itu, intimasi dapat terbentuk apabila individu telah sukses melampaui tugas sistem perkembangan pada tahap sebelumnya (Papalia, Olds, and Feldman 2008). Pada sistem perkembangan psikoseksual, Erikson (1969 dalam Ega, 2012) mengungkapkan bahwa jenis kelamin dapat berpengaruh pada perkembangan intimasi individu. Penelitian oleh Jones dan Dembo (1989) mendapatkan hasil bahwa perempuan mempunyai tingkat intimasi lebih tinggi daripada laki-laki (Ega 2012). Penelitian oleh Ishak et al., (2011) mendapatkan bahwa kecerdasan emosional pada individu berusia lebih dari 21 tahun lebih baik daripada individu berusia di bawah 21 tahun.

Orang tua merupakan tempat pembelajaran bagi anak yang pertama kali. Sikap orang tua dalam mengasuh anak dapat dilihat dari cara orang tua merespon dan memenuhi kebutuhan anak (Utami and Murti 2017). Peneliti berasumsi perkembangan psikososial mahasiswa dapat dipengaruhi oleh pola asuh orang tua. Pada usia dewasa muda, individu diharapkan dapat menjalin persahabatan dan hubungan dengan individu lain. Apabila orang tua terlalu membatasi anak dengan lingkungan sekitar, maka perkembangan psikologi anak akan terhambat karena anak tidak 
mampu menjalin hubungan dengan individu lain maupun lingkungan sekitar. Penelitian yang dilakukan oleh Yulianto, Lestari and Suwito (2017) mendapatkan bahwa adanya hubungan antara pola asuh orang tua dengan perkembangan psikososial anak.

Kegagalan perkembangan psikososial pada dewasa muda yaitu tahap keintiman dapat menimbulkan masalah baru seperti adanya masalah pekerjaan, masalah rumah tangga, dan masalah keuangan akibat pemenuhan kebutuhan hidup yang berhubungan dengan kondisi internal individu seperti faktor sosial, keluarga, lapangan pekerjaan, maupun lingkungan dan aktivitas sehari-hari dalam kampus bagi mahasiswa sehingga diperlukan adanya pembimbingan dalam mengembangkan psikosial pada individu, terutama pada dewasa muda supaya tugas perkembangan psikosial pada tahap tersebut dapat tercapai. Apabila tugas perkembangan psikosisal pada dewasa muda tidak tercapai, dapat menyebabkan individu mengalami kesulitan dalam menjalin hubungan dekat dengan individu lain dan individu akan merasa tidak percaya diri sehingga individu akan menarik diri dari sosial (Fortinash and Worret 2012).

\section{SIMPULAN}

Hasil peneltian ini menunjukkan sebagian besar karakteristik umur dewasa muda berusia 18 tahun dan berjenis kelamin perempuan. Perkembangan psikososial pada dewasa muda berada pada tahap intimasi dengan hasil sebagian besar mahasiswa memiliki perkembangan psikososial kurang optimal. Penelitian ini menyatakan tidak terdapat hubungan yang signifikan antara perkembangan psikososial mahasiswa dengan usia mahasiswa dan terdapat hubungan yang signifikan antara perkembangan psikososial mahasiswa dengan jenis kelamin mahasiswa.

\section{DAFTAR PUSTAKA}

Azizah, Fajriyati Nur. 2015. "Pengalaman Depresi Orang Dewasa Dengan HIV/AIDS Dalam Menjalani Tugas Perkembangan Psikososial.” Universitas Indonesia.

Ega, Agustine. 2012. "Pengaruh Terapi Kelompok Terapeutik; Dewasa Muda Terhadap Perkembangan Intimasi Pada Mahasiswa Akademi Keperawatan Kabupaten Subang Dan Sumedang Provisi Jawa Barat." Universitas Indonesia.

Fortinash, Katherine M., and Patricia A. Holoday Worret. 2012. Psychiatric Mental Health Nursing. 3rd Editio. Mosby, USA.

Hidayat, Aziz Alimul. 2009. Pengantar Kebutuhan Dasar Manusia. Jakarta: Salemba Medika.

Indonesia, Sekretariat Kabinet Republik. 2017. 60\% Penduduk Usia Produktif, Presiden Jokowi: Ini Peluang Kita Menangkan 
Persaingan. Indonesia.

Ishak, NoorAzniza et al. 2011. "Moderating Effect of Gender and Age on the Relationship between Emotional Intelligence with Social and Academic Adjustment among First Year University Students." International Journal of Psychological Studies 3: 78-79.

Latifah, Dewi. 2005. "Fungsi Dan Dampak Persahabatan Lawan Jenis Terhadap Kepuasan Pernikahan Dewasa Muda Dan Dewasa Madya." Universitas Indonesia.

Papalia, D. E, S. W Olds, and Feldman. 2008. Human Development Psikologi Perkembangan. 13th ed. Jakarta: Kencana Prenada Media Group.

Pieter, Herri Zan, Bethsaida Janiwarti, and Marti Saragih. 2011. Pengantar Psikopatologi Untuk Keperawatan. Edisi 1. Jakarta: Kencana.

Potter, Patricia A., and Anne Griffyn Perry. 2005. Fundamental Keperawatan: Konsep, Proses Dan Praktis. eds. Yasmin Asih et al. Jakarta: EGC.

Santrock, Jhon W. 2003. Life-Span Development : Perkembangan Masa Hidup Jilid 2. Jakarta: Erlangga.

Utami, Cahyaning, and Heru Astikasari Setya Murti. 2017. "Hubungan Antara Kelekatan Dengan Orang Tua Dan Keintiman Dalam Berpacaran Pada Dewasa Awal." Universitas Kristen Satya Wacana.

Wiska, Nadia. 2014. "Hubungan Usia, Jenis Kelamin, Masa Studi Dan Pengalaman Praktikum Di Rumah Sakit Dengan Tingkat Kecerdasan Emosional Mahasiswa Ilmu Keperawatan." Universitas Indonesia.

Yulianto, Yufi Aris Lestari, and Elok
Diniarti Suwito. 2017. "Hubungan Pola Asuh Orang Tua Dengan Perkembangan Psikososial Anak Di TK PKK XI Winong Gempol Kabupaten Pasuruan." Jurnal Nurse and Health 6(2): 21-29. 